\title{
Recent historical land use change on the South Downs, United Kingdom
}

\author{
NIALL G. BURNSIDE*, ROGER F. SMITH AND STEPHEN WAITE \\ Biogeography and Ecology Research Group (BERG), School of the Environment, University of Brighton, Moulsecoomb, Brighton, BN2 4GJ, \\ United Kingdom
}

Date submitted: 19 December 2001 Date accepted: 25 September 2002

\section{SUMMARY}

There is considerable interest in the fragmentation and loss of natural and semi-natural habitats, but few studies have examined the dynamics and mechanisms of change. A temporal analysis of landscape change on the South Downs in Sussex, UK, provides a clear description of the process of change over the 20 years 1971-1991. Transition probabilities were calculated from digital interpretations of an aerial photography time series of West Sussex. The analysis enabled quantitative comparison of landscape mosaics within different landscape ecoregions and under different management regimes to be made. Past changes in land use have produced a fragmented downland landscape. The key land conversion sequences identified show a substantial transition towards arable production, often at the expense of the internationally and nationally important unimproved grassland systems. A geographical information system facilitated greater understanding of the environmental and topographical characteristics of land converted to arable and other uses, and highlighted areas for protection and potential restoration. The patterns of land-use conversion observed in the study provide a landscape-scale planning tool for assessing the potential impact of agri-environmental policies, plans, and programmes in semi-natural grassland habitats.

Keymords: land-use change, geographical information systems, calcareous grassland, ecoregions

\section{INTRODUCTION}

Calcareous grasslands are of international conservation importance (Department of the Environment 1994; UK Biodiversity Group 1998), and recognized as species-rich plagio-climax communities, reliant upon appropriate grazing by wild or domesticated animals or cutting management (Smith 1980; Bacon 1990; Rodwell 1990; Schläpfer et al. 1998). Without sympathetic management the current grassland would change through successional processes to deciduous scrub and ultimately mixed woodland. The UK Biodiversity Action Plan (Department of the Environment 1994), the UK's initiative to maintain and enhance biodiver-

* Correspondence: Dr Niall G. Burnside Tel: +44 1273642425 Fax: +44 1273642285 e-mail: N.G.Burnside@brighton.ac.uk sity, identifies lowland calcareous grassland systems as among the most species rich and diverse habitats nationally.

Agriculture is the principal land-use on the South Downs, and the sympathetic management of this activity is considered to be of primary importance for the maintenance of biodiversity (Hutchings \& Booth 1996; Sussex Downs Conservation Board 1996a; Muller et al. 1998; UK Biodiversity Group 1998). Since the Second World War, the landscape of the South Downs has been transformed by agricultural activities. The trend has been from the livestock farming on unimproved grassland towards more profitable arable and high production grassland systems. Green (1990) records that between 1947 and 1981 large areas of permanent downland, heathland and woodland nationally were ploughed and consequently the area of unimproved and semi-improved grassland decreased by around $40 \%$. Due to economic pressures, partly as a consequence of membership of the European Union, farming in southern England has moved progressively towards barley and wheat production (Green 1990). Significant tracts of downland have been ploughed and the availability of inorganic fertilizers has meant that in some areas even thin nutrient-poor soils have been brought into arable production. In many cases, the remaining grassland fragments have been modified and have lost much of their diverse assemblages of flora and fauna (Fisher \& Stocklin 1997; Brandon 1998). During this post-war boom, reductions in flock and herd sizes resulted in the abandonment by agriculture of some areas of steep lowland escarpments (Green 1990). Historically, because of the difficulty of mechanized access to steep north-facing escapement slopes of the South Downs, these areas had remained uncultivated. Yet, this withdrawal of management, in association with the decline in rabbit grazing following the arrival of the Myxoma virus, is suggested by some workers to have led to the development of less floristically diverse grassland and scrub communities (Sussex Wildlife Trust 1993; Hopkins 1996).

Under the current price support system operated within the Common Agricultural Policy (CAP), the intensification of farming continues to pose a serious threat to natural and semi-natural habitats (Blackwood \& Tubbs 1970; Green 1990; Brandon 1998; Burnside et al. 1998a). In the UK, organizations with responsibility for management and conservation such as the Department of Environment, Food and Rural Affairs (DEFRA) and the Sussex Downs Conservation Board (SDCB) are attempting to reconcile the conflicting interests of agriculture and nature conservation on the downland by offering guidance to farmers and encouraging 'environmentally sensitive' farming practices (Ministry 
of Agriculture Fisheries and Food 1997) (Table 1). The South Downs is one of five areas of England awarded Stage 1 notification in 1987, via the Environmentally Sensitive Areas (ESA) scheme (Ministry of Agriculture, Fisheries \& Food 1997). The ESA scheme in operation on the South Downs recommends that top-level protection (tier 1) be given to grassland sites present on the scarp and in the dry valleys (the protection and management of existing features), whilst tier 3 prescriptions (reversion of arable land) are applied to other areas of arable cultivation on the southern dip slope and inter-fluves and designed to encourage the reversion of arable land to chalk grassland or permanent pasture. Despite this designation and management prescription it appears that the semi-improved and unimproved grassland areas in the region remain under threat (Burnside et al. 1998b; Belden 2000; Burnside 2000).

The objectives of the analysis undertaken were to establish the extent and effects of recent human intervention and management on unimproved grasslands on the South Downs, UK. The time period investigated encompassed the immediate aftermath of the agricultural intensification, which occurred in the 1960s and 1970s, and the initial implementation of subsequent planning and management policies aimed at protecting and enhancing the nationally and internationally important calcareous grassland resource. Thus, the study allowed the effects of market driven and policy driven changes on the landscape between 1971 and 1991 to be quantified. Within the study area distinct 'ecoregions' characterized by management, topography and habitat characteristics were identified and used in the analysis and description of the region. Although particular emphasis was placed upon the biologically important unimproved grassland systems, other land-use categories fundamental to the landscape mosaic were also considered. Landscape fragmentation and conversion between different land classes and uses are important characteristics of the landscape mosaic. The study aimed to quantify spatial and temporal patterns of fragmentation.

\section{METHODS}

Temporal land-use and habitat data were used to estimate transitional probabilities and evaluate land-use and habitat change within a rural and agricultural landscape. Such an approach can provide a clear description of the texture and dynamics of the landscapes. This type of modelling approach provides a means by which the different dynamics associated with management options can be evaluated. (Buse 1992; Poudevigne \& Alard 1997)

The main data source was aerial photographs completed and interpreted into the relevant land classes and ground truthed by West Sussex County Council (West Sussex County Council \& English Nature 1996). The aerial images were rasterized to produce a uniform and consistent coverage detailing 15 land-use classes on a 100-m grid basis over an area of $47338 \mathrm{ha}$. A geographical information system (GIS) database was established containing land-use data, which made possible comparisons of land conversion on the South Downs among periods 1971, 1981 and 1991. The original classification was aggregated for the purpose of this study into seven classes, namely arable (arable and improved grassland), developed (urban areas and farmsteads), plantation (woodland plantation areas), grassland (unimproved grassland, c. $75 \%$ of which is calcareous grassland), scrub (scrub habitats), wooded (deciduous and coniferous woodland) and 'other' (orchards, surface-water, marshes, quarries and heathland) (Table 2). This reclassification was undertaken to reflect the major patterns of land-use change.

The South Downs landscape may be divided into various 'ecoregions'. Bailey (1983) defined ecoregions as large geographical regions that include multiple ecosystems, which are often similar in ecological function. Analysis of the landscape on an ecoregion basis made possible the identification of differences in the sequences of conversion for land-use classes (Table 3) within distinct landscape areas.

The Sussex Downs Conservation Board (1996b) recognize 15 ecoregions or landscape character areas within the South Downs Area of Outstanding Natural Beauty, 10 of which are specific to the chalk downland. The South Downs

Table 1 The ESA scheme and the tiered structure on the South Downs (Ministry of Agriculture, Fisheries and Food 1997).

\begin{tabular}{ll}
\hline \hline Tier & Scheme \\
\hline Tier 1 & $\begin{array}{l}\text { Chalk grassland that has not been ploughed or reseeded in the past five years is suitable. The aim is to regenerate and protect the } \\
\text { high species richness of the grassland by reverting to old farming methods. Fertilizers are banned, grazing and mowing are } \\
\text { encouraged as is scrub management but all activities are subject to an ecologically friendly time scale. However, mowing may be } \\
\text { prevented by the presence of nesting birds }\end{array}$
\end{tabular}

Tier 3a Potential arable land is suited to this method of regaining species rich grassland on chalk. The main aim is to reduce the nutrients in the soil. This is done by mowing and removing the grass with as little machine work as possible. Seed mixtures can be used to regenerate the grass where appropriate. The land in this program is ideal for a buffer zone between intensive agriculture and species rich sites

Tier $3 \mathrm{~b}$ This has the same entry requirements as tier $3 \mathrm{a}$ but is designed to produce permanent grassland where the main priority is agricultural production. Fertilizers can be added after three years at a reduced rate and field operations are controlled but not eliminated 
Table 2 Land-use totals (ha) and areas (\%) for each land use within the Western Downs, UK.

\begin{tabular}{|c|c|c|c|c|c|c|c|}
\hline Year & Arable & Developed & Plantation & $\begin{array}{c}\text { Unimproved } \\
\text { grassland }\end{array}$ & Scrub & Wooded & $\begin{array}{c}\text { Other } \\
\text { land uses }\end{array}$ \\
\hline 1971 & $\begin{array}{l}28176 \\
59.5 \%\end{array}$ & $\begin{array}{l}1023 \\
2.2 \%\end{array}$ & $\begin{array}{c}5282 \\
11.2 \%\end{array}$ & $\begin{array}{c}4729 \\
10.0 \%\end{array}$ & $\begin{array}{l}1332 \\
2.8 \%\end{array}$ & $\begin{array}{c}5621 \\
11.9 \%\end{array}$ & $\begin{array}{l}1175 \\
3.0 \%\end{array}$ \\
\hline 1981 & $\begin{array}{l}29698 \\
62.7 \%\end{array}$ & $\begin{array}{l}1174 \\
2.5 \%\end{array}$ & $\begin{array}{l}4572 \\
9.7 \%\end{array}$ & $\begin{array}{l}3212 \\
6.8 \%\end{array}$ & $\begin{array}{l}1244 \\
2.6 \%\end{array}$ & $\begin{array}{c}6225 \\
13.2 \%\end{array}$ & $\begin{array}{l}1213 \\
2.6 \%\end{array}$ \\
\hline 1991 & $\begin{array}{c}30689 \\
64.8 \%\end{array}$ & $\begin{array}{l}1428 \\
3.0 \%\end{array}$ & $\begin{array}{c}5872 \\
12.45\end{array}$ & $\begin{array}{l}1976 \\
4.2 \%\end{array}$ & $\begin{array}{l}1142 \\
2.4 \%\end{array}$ & $\begin{array}{c}4865 \\
10.3 \%\end{array}$ & $\begin{array}{l}1366 \\
2.9 \%\end{array}$ \\
\hline
\end{tabular}

Table 3 The division of the data set into ecoregions.

\begin{tabular}{ll}
\hline \hline Criteria & Ecoregions \\
\hline Management & Land within ESA - Non-ESA land \\
Topography & $\begin{array}{l}\text { Land on the scarp slope - Land on the dip } \\
\text { slope }\end{array}$ \\
Habitat type & $\begin{array}{c}\text { Land considered open downland - Land } \\
\text { considered wooded downland }\end{array}$ \\
\hline \hline
\end{tabular}

Conservation Board identified these ecoregions from an essentially subjective analysis of landscape and visual characteristics.

The GIS was used to establish the area of each land-use class that remained in that class or made a transition to another land-use class within each decade (1971-1981, 1981-1991), and thus, rates of land-use change, diversity values, and transition probabilities were determined. GIS analysis was performed on ArcView 3.x software, Environmental Systems Research Institute. The transitional totals (ha) were then used to calculate the transitional probabilities for each land-use change within both decades. Transition probabilities were calculated using figures obtained from a GIS analysis of the data sets. The transition probabilities measured gave a maximum likelihood estimate of the 'probability' of a given land-use class making a 'transition' to another land-use class within either 10-year period.

The landscape structure and spatial characteristics of the temporal data sets were assessed at the landscape scale using FRAGSTATS 2.0 (McGarigal \& Marks 1994). This allowed quantitative analysis of both the landscape and land-use structure and identified changes in spatial characteristics over time. Key descriptors used included nearest-neighbour distance, shape index (SI) and coefficient of variation (CV\%). Nearest neighbour distance was defined as the distance 'edge to edge', from a patch to the nearest neighbouring patch of the same type. The shape index gives a quantitative measure of the patch shape. A circular patch (vector) or square patch (raster) would have a SI value of 1 and SI increases as shape becomes more complex. The coefficient of variation, being equal to the standard deviation of a measure divided by its mean gives a dimensionless and scale independent measure of variation allowing comparison to be made between the different variables (Waite 2000). Details of the calculation and interpretation of other FRAGSTAT output may be found in McGarigal and Marks (1994) and Forman (1997). Further analysis was performed at the ecoregion scale, with the assessment of the dominance of land-use categories at each date using the Shannon evenness index (f) (Forman 1997; Farina 1998).

Principal Component Analysis (PCA) was used to examine the differences in the ecoregions for all seven landuse classes over time. PCA analysis was performed on the scarp and dip slopes, and wooded and open downs ecoregions. PCA ordination provided an objective method for representing complex datasets (Baker \& Weisberg 1997; Waite 2000). In the present study, PCA ordination was used to assess the similarity and variation between ecoregions and their land-use categories over the 20-year period.

\section{RESULTS}

During 1971-1991, considerable changes in land-use occurred on the Western South Downs (Table 2). Arable land-use occupied $60-65 \%$ of the landscape, with unimproved grassland coverage being $4-10 \%$. The other six land-uses made up the remaining areas, contributing around 30\% (Table 2).

\section{Landscape scale}

At the landscape scale, there was a reduction in the number of patches over the 20-year period with the most marked reduction occurring between 1981 and 1991. In 1981, the landscape contained 3937 individual land-use patches regardless of type, and by 1991, this figure had dropped to 3115 patches. Patch density (patches $100 \mathrm{ha}^{-1}$ ), showed a corresponding drop, which was most marked between 1981 (8.3 patches $\left.100 \mathrm{ha}^{-1}\right)$ and $1991\left(6.7\right.$ patches $\left.100 \mathrm{ha}^{-1}\right)$. The transformation of the landscape to a more homogeneous state is further illustrated by the increase in the mean patch area. In 1971, the mean patch area was $11.9(\mathrm{SD} \pm 294.5)$ ha, by 1981 the mean patch area had increased to 12.0 ( $\mathrm{SD} \pm 461.9)$ ha, and then by 1991 a further increase occurred to 15.0 (SD $\pm 536.6)$ ha.

There was a reduction in landscape evenness $(\mathcal{F})$ in the 20 -year period. In 1971, landscape evenness was 0.49. By 1981, the landscape evenness had dropped to 0.47 , and by 
Table 4 Shannon evenness $(\mathcal{F})$ index values for all ecoregions.

\begin{tabular}{llll}
\hline \hline Ecoregion & 1971 & 1981 & 1991 \\
\hline Open down & 0.50 & 0.48 & 0.47 \\
Wooded down & 0.44 & 0.42 & 0.40 \\
ESA & 0.39 & 0.38 & 0.36 \\
Non-ESA & 0.49 & 0.47 & 0.46 \\
Scarp slope & 0.48 & 0.46 & 0.47 \\
Dip slope & 0.49 & 0.47 & 0.44 \\
\hline \hline
\end{tabular}

1991, landscape evenness had further decreased to 0.46 respectively (Table 4).

\section{Land-use scale}

At land-use level, the growing dominance of arable land and improved pasture on the South Downs was a predominant feature between 1971 and 1991. The total area of arable landuse showed a progressive increase from 28176 ha (1971) to 29698 ha (1981) to 30689 ha (1991) (Table 2). The number of arable patches within the landscape remained relatively static over the temporal sequence, suggesting that large areas were simply being appended to existing arable patches and added to the homogenous nature of the landscape.

The shape index dropped progressively from 31.0 (1971) to 30.6 (1981) and 28.1 (1991), depicting a move towards more uniform patch shapes and a drop in complexity of landscape patch shapes. Mean nearest neighbour distance remains relatively static throughout the temporal sequence for arable patches.

There was a reduction in the area of unimproved grassland within the downland landscape (Fig. 1). The total area of unimproved grassland initially dropped from 4729 ha (1971) to 3212 ha (1981), and then further decreased to 1976 ha (1991). The number of patches present within the landscape dropped from 815 patches in 1971, to 701 patches in 1981 and 227 patches in 1991. Mean patch size of the grassland fragments showed an initial decrease from 5.8 (SD $\pm 17.05)$ ha to $4.6( \pm 15.83)$ ha between 1971 and 1981 , but between 1981 and 1991 the mean patch area increased to 8.7 $( \pm 21.89)$ ha. The associated $\mathrm{CV} \%$ values suggest that between 1971 and 1981, the area of the surviving patches of grassland became more variable. The $\mathrm{CV} \%$ increased from $293.9 \%$ to $345.7 \%$. Over the period 1981 to 1991 , the size of persisting patches of grassland became more uniform with the CV\% decreasing from $345.7 \%$ to $251.4 \%$.

The grassland fragments also displayed a marked increase in the mean nearest neighbour distance between patches. The mean nearest neighbour distance was 187 (SD \pm 139.6$)$ $\mathrm{m}$ in 1971,225 ( \pm 174.4$) \mathrm{m}$ by 1981 , and 341 ( \pm 382.6$) \mathrm{m}$ by 1991.

Scrubland cover declined in area between 1971 and 1981, from a total area of 1332 ha divided into 586 patches in 1971 to 1244 ha divided into 534 patches by 1981 . Further reductions occurred between 1981 and 1991 with a final area of 1142 ha split into 369 patches. Between 1971 and 1981, the

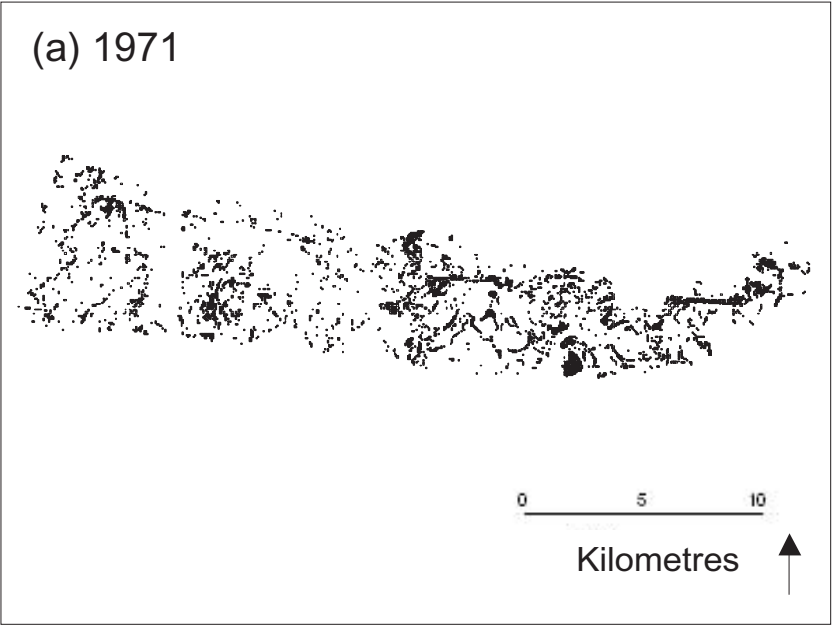

(b) 1981

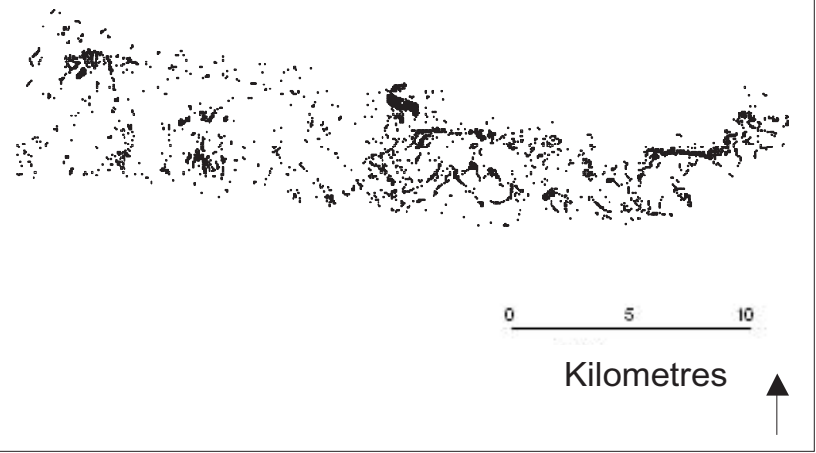

(c) 1991

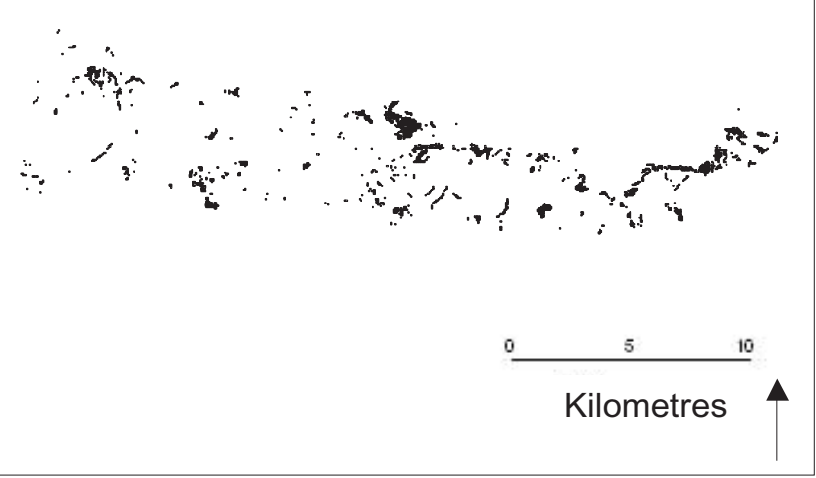

Figure 1 Unimproved grassland present on the South Downs (West Sussex) (a) 1971, (b) 1981 and (c) 1991.

mean nearest neighbour distance between patches of scrub changed little. However, between 1981 and 1991, the mean nearest neighbour distance between scrub fragments increased from 257 (SD \pm 250.1$) \mathrm{m}$ to 325 (SD \pm 319.1$) \mathrm{m}$.

Variables associated with the woodland and plantation land-use classes remained relatively static between 1971 and 
1991, with total area and patch number varying little. Mean nearest neighbour distance did vary, however, increasing from $186(\mathrm{SD} \pm 201.8 ; \pm 190.9) \mathrm{m}$ in 1971 and 1981 , but increasing to 220 (SD \pm 214.3 ) $\mathrm{m}$ by 1991 .

\section{Ecoregion analysis}

There were significant losses to the grassland biotope evident within all ecoregions (Table 5). There were, however, differences in the nature of land transformation that occurred on the dip slopes and land conversion on the steep north-facing scarp slopes. Unimproved grassland was reduced by over $50 \%$ in each 10 -year period on the dip slope with a high proportion of grassland being converted to other uses (Table 5). Conversely, grassland conversion was substantially less on the scarp slope. Twenty-three per cent of grassland was lost between 1971 and 1981, and 16\% lost between 1981 and 1991 (Table 5).

In contrast, arable land classes steadily increased throughout the temporal sequence, although there were clear differences between ecoregions. Conversion of land to arable uses was strongest within the open downland and southern dip slopes and inter-fluves (Table 5).

The land-use totals for the plantation and wooded areas also showed different trends between ecoregion pairs (Table 5). Woodland increased in 1971-1981 within all but the open downland ecoregion, while in 1981-1991 wooded land showed a reduction in area. A contrasting pattern of change was shown by plantations, which declined in area in the first time period, in all but two ecoregions, but increased from $21 \%$ to $54 \%$ during the second time period. Within all ecoregions, developed land (buildings and roads) increased within the study period (Table 5).
Ecoregion evenness $(7)$ values showed moderate decreases in landscape evenness over the 20-year period (Table 4), suggesting a more homogeneous landscape mosaic. A contrasting pattern, however, was observed in one ecoregion (Table 4). The scarp slope indices demonstrated a decrease in evenness from 1971 to 1981 , but between 1981 and 1991 there was a small transformation back to a more heterogeneous landscape mosaic.

\section{Transitional characteristics}

The arable-to-arable transformation dominated the arable transition matrices, with all other transition probabilities being less than 0.05 within all ecoregions (Fig. 2). The ecoregion analysis showed that during the period 1971-1981 arable land had a probability of 0.958 (on the scarp slopes) and 0.971 (on the dip slope) of remaining as arable land. The probability of a unit of arable land remaining in this class dropped between 1981-1991 to 0.923 (scarp) and 0.944 (dip slope) (Fig. 2).

A relatively small proportion of grassland patches remained as undisturbed grassland, irrespective of the ecoregion studied (Fig. 2). During this time the north-facing scarp slopes offered the greatest protection to the unimproved grassland of the South Downs. On the scarp slopes, grassland had a probability of 0.590 (1971-1981) and 0.555 (1981-1991) of remaining as grassland. In all other ecoregions the probabilities of retaining grassland patches were lower than those found on the scarp, and ranged from 0.559 (open down) to 0.199 (wooded) (Fig. 2). The grassland habitat displayed high probabilities of transition to arable land-use within both 10 -year periods. Values between 0.470 (dip slope) and 0.234 (scarp) illustrate the levels of grassland

Table 5 Land-use area totals (ha) for each ecoregion at each time period sampled.

\begin{tabular}{|c|c|c|c|c|c|c|c|c|}
\hline Year & Ecoregion & Arable & Developed & Plantation & $\begin{array}{l}\text { Unimproved } \\
\text { grassland }\end{array}$ & Scrub & Wooded & $\begin{array}{l}\text { Other } \\
\text { land uses }\end{array}$ \\
\hline \multirow[t]{6}{*}{1971} & Open down & 12496 & 416 & 594 & 2779 & 664 & 1420 & 533 \\
\hline & Wooded down & 15680 & 607 & 4688 & 1950 & 668 & 4201 & 642 \\
\hline & ESA & 3168 & 4 & 16 & 1503 & 332 & 270 & 29 \\
\hline & Non-ESA & 25008 & 1019 & 5266 & 3227 & 1000 & 5351 & 1146 \\
\hline & Scarp slope & 7764 & 431 & 344 & 1498 & 478 & 1630 & 369 \\
\hline & Dip slope & 20412 & 592 & 4938 & 3231 & 854 & 3991 & 806 \\
\hline \multirow[t]{6}{*}{1981} & Open down & 13307 & 492 & 617 & 1881 & 639 & 1379 & 587 \\
\hline & Wooded down & 16391 & 682 & 3955 & 1331 & 605 & 4846 & 626 \\
\hline & $\mathrm{ESA}$ & 3381 & 4 & 28 & 1244 & 335 & 292 & 38 \\
\hline & Non-ESA & 26317 & 1170 & 4544 & 1969 & 909 & 5933 & 1175 \\
\hline & Scarp slope & 8061 & 482 & 321 & 1154 & 466 & 1666 & 364 \\
\hline & Dip slope & 21637 & 692 & 4251 & 2058 & 778 & 4559 & 849 \\
\hline \multirow[t]{6}{*}{1971} & Open down & 13766 & 618 & 799 & 1318 & 447 & 1326 & 628 \\
\hline & Wooded down & 16923 & 810 & 5073 & 658 & 695 & 3539 & 738 \\
\hline & ESA & 3761 & 18 & 61 & 851 & 233 & 336 & 62 \\
\hline & Non-ESA & 26928 & 1410 & 5811 & 1125 & 910 & 4529 & 1304 \\
\hline & Scarp slope & 8106 & 556 & 476 & 971 & 461 & 1509 & 435 \\
\hline & Dip slope & 22583 & 872 & 5396 & 1005 & 681 & 3356 & 931 \\
\hline
\end{tabular}


(a) Grassland 1971-1981

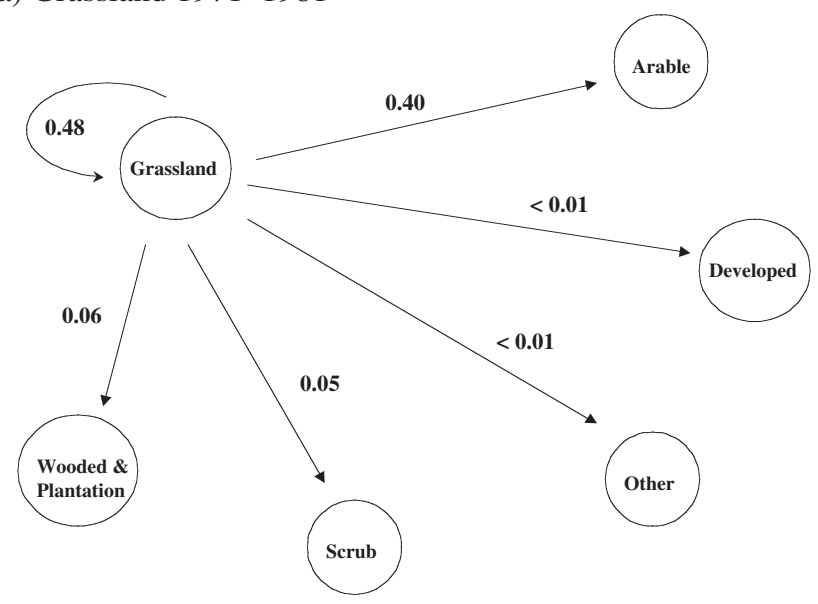

(b) Grassland 1981-1991

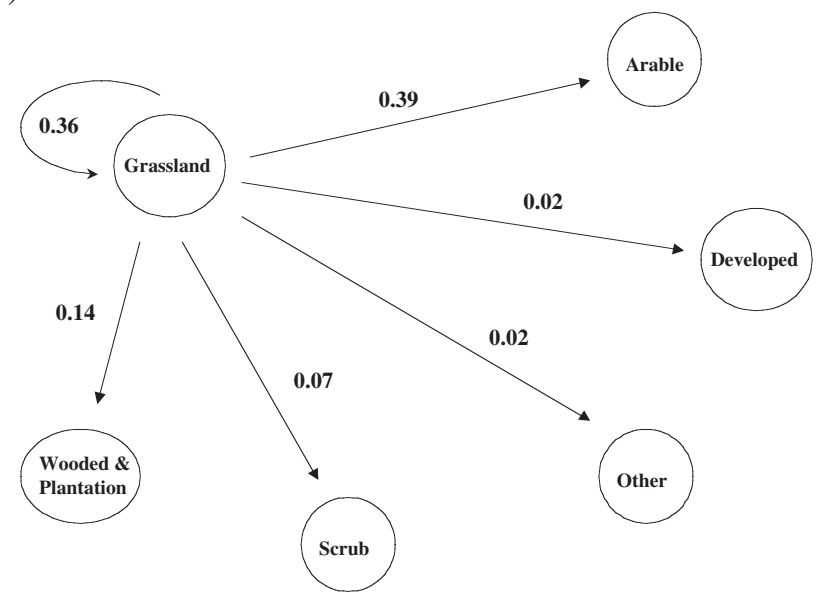

(c) Arable 1971-1981

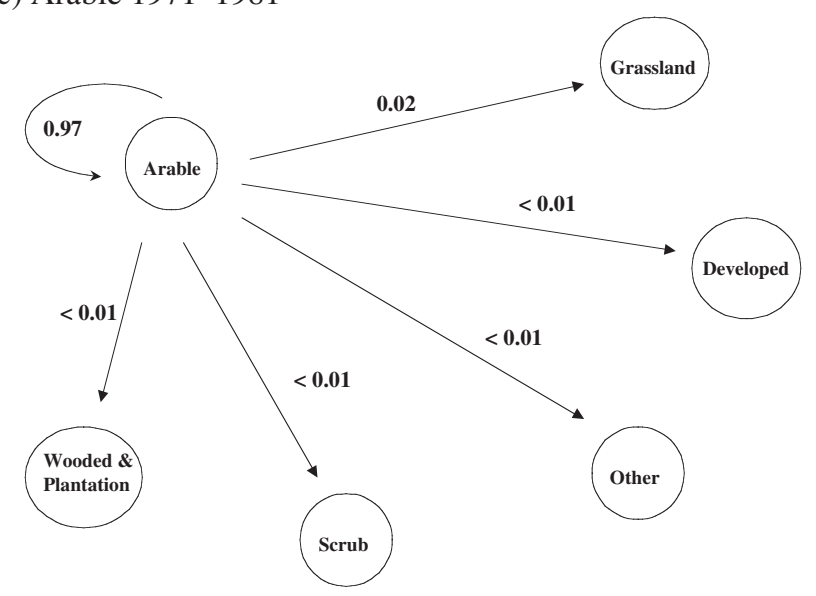

(d) Arable 1981-1991

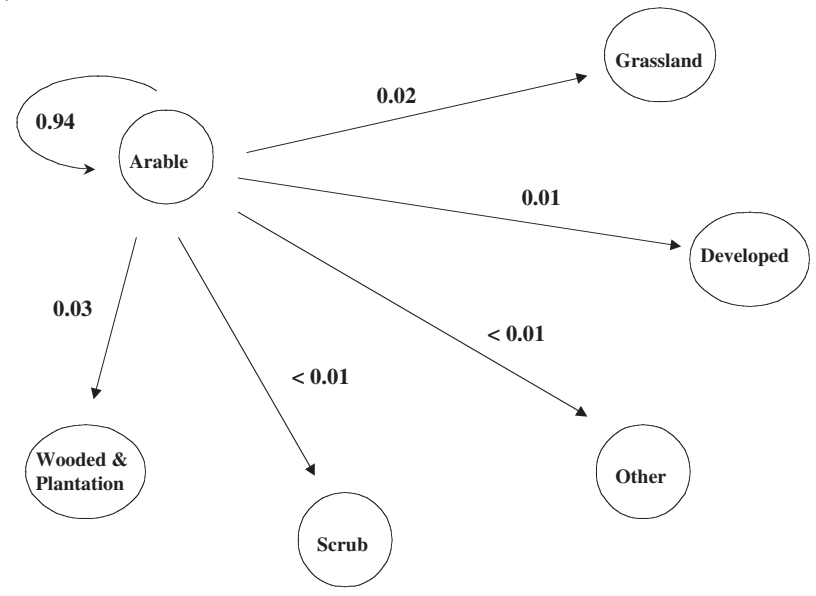

Figure 2 Grassland and arable land-use transition probabilities within the Western Downs, UK, for $(a, c)$ 1971-1981 and (b, $d)$ 1981-1991.

conversion to arable. Significant losses of grassland also occurred as a result of transitions to scrub, with probability equivalents of 0.044 (open down) increasing to 0.089 (wooded). In addition, large areas of grassland made transitions to both wooded and plantation land classes. For all major land-use classes within each ecoregion studied, the transition to developed land (buildings and roads) increased during the study period.

\section{Multivariate ordination of the patterns land-use change}

PCA analysis of the scarp and dip slope, and open and wooded downland ecoregions identified clear distinctions among ecoregions. Principal Component 1 reflects the initial differences between each individual ecoregion in terms of the abundance of land-use classes, whilst Principal Component 2 illustrates the changes in the nature of landscape in each ecoregion over the entire temporal sequence (Fig. 3). For the topographic and habitat ecoregions, the ordination plot shows two main gradients (Fig. 3). The six ecoregions were clearly separated along the first component, which accounted for $70.8 \%$ (eigenvalue $=5.6607$ ) of the variation in the dataset. A second gradient was also apparent along the second component axis, which accounted for $19.9 \%$ (eigenvalue $=$ 1.5934) of the variation within the dataset.

\section{DISCUSSION}

Analysis of the temporal dynamics of the Western South Downs landscape between 1971 and 1991 reflects the intensification of agriculture. There was an overall loss of 2753 ha of unimproved grassland between 1971 and 1991, the transition probabilities showing that the loss was principally attributable to agricultural intensification. It is unclear, however, whether individual losses were due to the application of fertilizers or the plough. By 1991, arable land-use classes had increased by 2513 ha and dominated the landscape. Total 


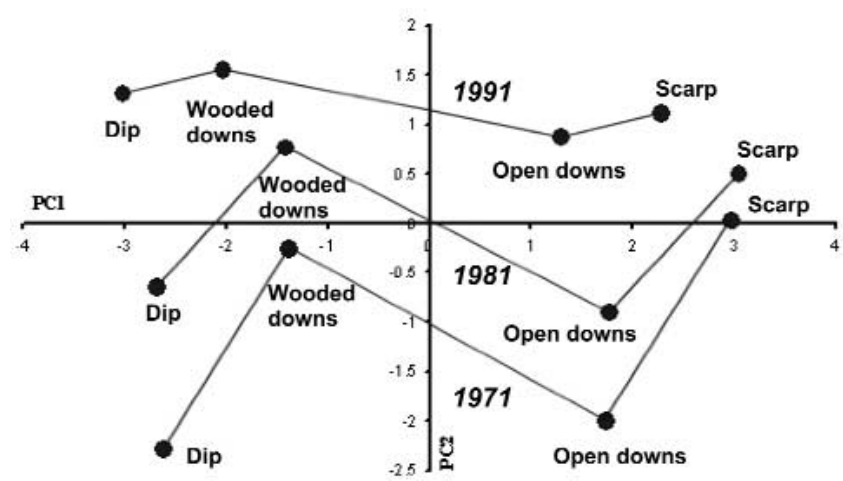

Figure 3 Ordination plot of the scarp and dip slopes, and open and wooded downs for 1971, 1981 and 1991.

patch number for the landscape dropped throughout the time sequence, and the systematic drop in patch density calculations corroborated this finding.

Temporal fluxes were apparent within the remaining land-use classes but, at the landscape scale, percentage cover values showed no significant variation. Wooded and plantation classes showed increases and decreases occurring both over and within the 20-year period. The wooded classes showed an initial increase between 1971 and 1981 possibly associated with the change of plantation areas to woodland by 1981, and then showed a significant drop of around 1360 ha. This drop coincided with the storms of 1987 and 1989, which had a significant impact on established woodland in the South East (West Sussex County Council \& English Nature 1996). If both classes are examined together, however, it appears that the total area of land under plantation and woodland remained relatively static over the two decades (10903-10737 ha). Unimproved grassland classes showed the greatest levels of reduction and loss, and further illustrate the trend of arable intensification on the Downs (Fig. 2). This pattern of increase in arable land and reductions in unimproved grassland suggests the intensification and large-scale mechanization of agricultural practices, and the assimilation of small grassland sites into larger homogeneous patches of crop or pastureland, are continuing trends. The increases in the mean landscape patch size throughout the period emphasize this point, along with the reduction in land-use diversity. Land-use groups, including developed, scrub and 'other' remained relatively unchanged over the 20-year study period.

These findings are similar to the national and European patterns observed by other workers during this period (Green 1990; Buse 1992; Poudevigne \& Alard 1997; Poudevigne et al. 1997). Both nationally and internationally, agricultural development can lead to the intensification of some areas and the abandonment of others. Previous work, which focused on the conversion of grasslands and other semi-natural habitats to intensive agricultural land uses, suggested that there is a corresponding decrease in biodiversity (Buse 1992; Wilcock \& Cooper 1993; Blackstock et al.
1995) and this decrease in biodiversity may be most marked on calcareous soils (Green 1990).

Within all ecoregions, arable land was the dominant land application and unimproved grassland was a diminishing resource. Comparison of the dip and scarp slopes shows the impact of topography even on modern intensive farming. The dip slopes and coombe valleys showed significant levels of grassland loss/conversion $(>50 \%)$, whereas the scarp slopes experienced less severe grassland loss $(<25 \%)$ over the same time period. This illustrates the influence of landscape on the degree of land conversion on the South Downs, and helps explain why the majority of the remaining unimproved grassland sites were on the northern scarp slopes. These results confirm earlier suggestions that the loss and conversion pressures experienced by semi-improved habitats are more apparent on land suited for cultivation (Buse 1992). Buse (1992) in a study on the Llyn Peninsula, showed that a significant relationship existed between habitat change and altitude, slope and soil conditions. On the South Downs, however, the $4.2 \%$ drop in unimproved grassland cover on the scarp slopes illustrates that land owners resorted to ever more marginal land as the landscape became more intensively used, and agricultural support schemes drove improvement and conversion.

The contrast between the wooded and open downland ecoregions demonstrates the continuing importance and significance of the wooded and plantation land-use classes on the western wooded downland in comparison to the more open eastern section. However, the majority of all other land conversions within these ecoregions were similar in character, and PCA suggested that land conversion sequences in operation on the wooded and open downland ecoregions were similar (Fig. 3).

The contrast between land managed under ESA agreements and non-ESA land (land within the general ESA region but not specifically managed) presents the opportunity to evaluate initial trends associated with the introduction of the ESA scheme in 1987. Our results suggest that, proportionally, the overall conversion of land-use classes to arable use was comparable in both management ecoregions. More positively, however, the loss or modification of unimproved grassland was substantially higher for the non-ESA land $(39-43 \%)$ than for the ESA land (17-32\%). These findings may either indicate that the scheme has had a positive impact upon farming practices, or that the land initially taken into the ESA scheme between 1981 and 1991 was land that historically had not been subject to the same levels of conversion as those found elsewhere within the landscape.

It is apparent that the land managed under ESA agreements has a proportionally higher representation of grassland than any other ecoregion studied. The analysis shows that in the decade before the scheme commenced, $23 \%$ of the land that later would be included within ESA tier agreements had some form of semi-improved pasture on it. These findings confirm the observations of Froud (1994) that early reviews of the scheme appeared to suggest that farmers were more 
likely to include (within the ESA scheme) land that was less intensively used, possibly due to the voluntary nature of the scheme. As a result, the effectiveness of the scheme to mitigate the effects of intensive farming within the landscape was reduced. It is, however, important to note that the ESA scheme (tier 1) also seeks to preserve existing features.

Our analysis also shows the limited impact of differences within the 'habitat' ecoregion division on land-use change dynamics on the South Downs. The apportionment of land into either open or wooded downland regions appeared to have little overall effect on the magnitude of land-use change and the overall land conversion sequences. This may suggest that some of the previously proposed landscape divisions of the South Downs do not fully reflect the functional landscape described within this analysis (Sussex Downs Conservation Board 1996b).

\section{CONCLUSIONS}

The land-use change and transitional characteristics described have provided an insight into the impact of past and current management approaches on the South Downs. Although the analysis focused on the downland of West Sussex (which represents $63.5 \%$ of the South Downs), it is suggested that the patterns observed reflect those of the South Downs as a whole.

On the South Downs landscape, change has been driven by anthropogenic factors, which favour arable land-use. Transition probabilities and low land-use diversity values show that larger arable land units have become increasingly important over the 20 -year period. The growth in agricultural land-use probably relates to land consolidation programmes that have resulted from agricultural intensification on the South Downs (Keymer \& Leach 1990; Morris et al. 1997). Significant loss of unimproved grassland has occurred between 1971 and 1991, and during this period the study failed to detect any substantial reduction in the loss of ecologically important habitats resulting from policy implementation.

Future developments of agri-environmental schemes, particularly of a targeted rather than voluntary nature, have the opportunity to influence the development and balance between agriculture and semi-natural habitats within the $\mathrm{UK}$, and reverse some of the more negative trends evident from past land-use conversion.

\section{ACKNOWLEDGEMENTS}

We thank Anne Griffiths and Peter Ross at West Sussex County Council for their support and provision of data for this project.

\section{References}

Bacon, J.C. (1990) The use of livestock in calcareous grassland management, Nature Conservancy Council. In: Calcareous
Grasslands - Ecology and Management, ed. Hillier, S.H., Walton, D.W.H. \& Wells, D.A., pp. 121-127. Huntingdon, UK: Bluntisham Books.

Bailey, R.G. (1983) Delineation of ecosystem regions. Environmental Management 7: 365-375.

Baker, W.L. \& Weisberg, P.J. (1997) Using GIS to model tree population parameters in the Rocky Mountain national park forest-tundra ecotone. Fournal of Biogeography 24: 513-526.

Belden, P. (2000) Sussex Chalk Grassland Habitat Action Plan. Unpublished report, Sussex Biodiversity Partnership, Storrington, Sussex, UK.

Blackstock, T.H., Stevens, J.P., Howe, E.A. \& Stevens, D.P. (1995) Changes in the extent and fragmentation of heathlands and other semi-natural habitats between 1920-22 and 1987-88 in the Llyn Peninsula, Wales, UK. Biological Conservation 72: 33-44.

Blackwood, J.W. \& Tubbs, C.R. (1970) A quantitative survey of chalk grassland in England. Biological Conservation 3: 1-5.

Brandon, P. (1998) The South Downs. Chichester, UK: Phillimore.

Burnside, N.G. (2000) Ecological management of the Sussex South Downs: application of GIS and landscape ecology. Ph.D. Thesis, University of Brighton, UK.

Burnside, N.G., Smith, R.F., Waite, S. \& Watson, N.M. (1998a) Analysis of land use change on the South Downs, United Kingdom. In: Key Concepts in Landscape Ecology, ed. J.W. Dover \& R.G.H. Bunce, pp. 123-128. UK-IALE European Congress Conference Proceedings. Garstang, UK: Colin Cross Printers.

Burnside, N.G., Smith, R.F., Waite, S. \& Watson, N.M. (1998b) Landscape ecology and the management of the South Downs, UK, In: Key Concepts in Landscape Ecology, ed. J.W. Dover \& R.G.H. Bunce, pp. 131-136. UK-IALE European Congress Conference Proceedings. Garstang, UK: Colin Cross Printers.

Buse, A. (1992) Environmental effects of land use change, as identified by habitat recording: a case study in the Llyn Peninsula, Wales. Fournal of Environmental Management 35: 131-151.

Department of the Environment (1994) Biodiversity - The UK Action Plan. London, UK: HMSO.

Farina, A. (1998) Principles and Methods in Landscape Ecology. London, UK: Chapman and Hall.

Fisher, M. \& Stocklin, J. (1997) Local extinctions of plants in remnants of extensively used calcareous grassland 1950-1985. Conservation Biology 11: 727-737.

Forman, R.T.T. (1997) Land Mosaics: The Ecology of Landscapes and Regions. Cambridge, UK: Cambridge University Press.

Froud, J. (1994) The impact of ESAs on lowland farming. Land Use Policy 11: 107-118.

Green, B.H. (1990) Agricultural intensification and the loss of habitat, species and amenity in British grasslands: a review of historical change and assessment of future prospects. Grass and Forage Science 45: 365-372.

Hopkins, J.J. (1996) Scrub ecology and conservation. British Wildlife 8: 28-36.

Hutchings, M.J. \& Booth, K.D. (1996) Studies of the feasibility of re-creating chalk grassland vegetation on ex-arable land. II. Germination and early survivorship of seedlings under different management regimes Fournal of Applied Ecology 33: 1182-1190

Keymer, R.J. \& Leach, S.J. (1990) Calcareous grassland - a limited resource in Britain, Nature Conservancy Council. In: Calcareous Grasslands - Ecology and Management, ed. S.H. Hillier, D.W.H. Walton \& D.A. Wells, pp. 11-17. Huntingdon, UK: Bluntisham Books. 
McGarigal, K. \& Marks, B.J. (1994) FRAGSTATS Spatial Pattern Analysis Program For Quantifying Landscape Structure. Version 2. Forest Science Department, Corvallis, Oregon, USA: Oregon State University.

Ministry of Agriculture, Fisheries and Food (1997) Environmentally Sensitive Areas: South Domns ESA. London, UK: MAFF Publications, Ministry of Agriculture, Fisheries and Food.

Morris, M.G., Thomas, J.A., Ward, L.K., Snazell, R.G., Pywell, R.F., Stevenson, M.J. \& Opdam, P. (1997) LANDECONET: the study of biodiversity in changing landscapes [www document]. URL http://www.nmw.ac.uk/ite/econet/contents.html

Muller, S., Dutoit, T., Alard, D. \& Grevilliot, F. (1998) Restoration and rehabilitation of species-rich grassland ecosystems in France: a review. Restoration Ecology 6: 94-101.

Poudevigne, I. \& Alard, D. (1997) Landscape and agricultural patterns in rural areas: a case study in the Brionne Basin, Normandy, France. Fournal of Environmental Management 50: 335-349.

Poudevigne, I, Rooij, S. van, Morin, P. \& Alard, D. (1997) Dynamics of rural landscapes and their main driving factors: a case study in the Seine Valley, Normandy, France. Landscape and Urban Planning 38: 93-103.

Rodwell, J.S. (1990) Types of calcareous grassland. In: Calcareous Grasslands - Ecology and Management, ed. S.H. Hillier, D.W.H. Walton \& D.A. Wells, pp. 29-34. Huntingdon, UK: Bluntisham Books.

Schläpfer, M., Zoller, H. \& Korner, C. (1998) Influences of mowing and grazing on plant species composition in calcareous grassland. Botanica Helvetica 108: 57-67.

Smith, C.J. (1980) Ecology of English Chalk. London, UK: Academic Press.

Sussex Wildlife Trust (1993) A Vision for the South Domns: Proposals by the Sussex Wildlife Trust for a Nem Strategy for the Sussex Chalklands. Henfield, UK: Sussex Wildlife Trust.

Sussex Downs Conservation Board (1996a) A Management Strategy for the Sussex Domns Area of Outstanding Natural Beauty. Storrington, West Sussex, UK: Sussex Downs Conservation Board \& The Countryside Commission.

Sussex Downs Conservation Board (1996b) The Landscape of the South Downs Area of Outstanding Natural Beauty. Storrington, West Sussex, UK: Sussex Downs Conservation Board \& The Countryside Commission.

UK Biodiversity Group (1998) Tranche 2 Action Plans Volume IITerrestrial and Freshmater Habitats. Peterborough, UK: English Nature.

Waite, S. (2000) Statistical Ecology: A Practical Guide. Harlow, UK: Prentice Hall.

West Sussex County Council \& English Nature (1996) Land Use and Habitat Change in West Sussex. Chichester, UK: WSCC Print Unit.

Wilcock, D. \& Cooper, A. (1993) Monitoring losses of semi-natural vegetation to agricultural grassland from satellite imagery in the Antrim Coast and Glens AONB, Northern Ireland. Fournal of Environmental Management 38: 157-169. 